\title{
Nutritional assessment of mutants of Calocybe indica produced by protoplast mutagenesis
}

\author{
Jatinder Kaur*, Harpreet S. Sodhi, Ravinder K. Jaswal and Shammi Kapoor \\ Department of Microbiology, Punjab Agricultural University, Ludhiana-141004 (Punjab), INDIA \\ *Corresponding author. E-mail: jatinder_sandhu@rediffmail.com
}

Received: March 3, 2015; Revised received: July 13, 2015; Accepted: September 2, 2015

\begin{abstract}
Mushrooms are rich source of protein, minerals and antioxidants. Nutritive value of mushrooms differs not only among genus but also among species. Nutritional content of mushrooms are being constantly reported. In present study, emphasis is laid on effect of mutational study on nutritional parameters of mushroom. A total of seven mutants of Calocybe indica obtained through physical and chemical mutagenic treatment were subjected to nutritional evaluation. Five mutants (CMU-5, CMN-9, CMN-11, CMN-2 and CMB-4) indicated higher protein content while ash content was also found more for all the mutants except CMN-9. Tocopherol content was also higher for all the mutants except CMN-3. $\beta$-carotene was more from 2 mutants, CMU-2 and CMN-9. Lycopene content was better in CMU-2, CMN-9, CME-2 and CMB-4 while ascorbic acid content for CMU-2 and CMN-3 was better than that of the parent. Fat content was found to be significantly low only in mutant CMN-9 $(1.24 \mathrm{~g} / 100 \mathrm{~g})$. CMN -9 , mutant obtained through NTG treatment, was found better than the parent, Ci-3, not only in protein content but also in amount of vitamin $A, C$ and $E$. It is indicated from the study that mutagenesis which leads to genotypic variation has effect on biochemical aspects as well. Therefore, various genetic manipulations can be exploited for nutritional enhancement aspects which need to be emphasized keeping in view the need of food quality in today's scenario.
\end{abstract}

Keywords: Antioxidants, Calocybe indica, fat, Mutagenesis, Protein

\section{INTRODUCTION}

Wild edible mushrooms are traditionally used by many Asian countries as food and medicine (Wang et al., 2014), and are becoming more and more important in our diet due to their culinary properties. Mushrooms are rich source of nutrients, particularly proteins, minerals like potassium, iron, copper, phosphorus and vitamins such as vitamin B, C, D and E (Chittaragi and Naika, 2014; Durgo et al., 2013). In addition to these, some other interesting features in the nutritional quantities of mushrooms are lack of starch, low fat content, low calorific value, and presence of a variety of sugars and their derivatives and high fiber content (Guo et al., 2010). Hence, they are said to be the delight of diabetics (Cooper, 2008). There is also growing interest in natural antioxidants for their potential role in the prevention of oxidative stress-related diseases, since synthetic antioxidants are being questioned due to their potential carcinogenic activity (Gan et al., 2013). Therefore, natural antioxidants such as tocopherol, polyphenols and carotenoid pigments are having a greater relevance in the protection against lipid oxidation. The use of mushrooms extracts as antioxidants is becoming increasingly popular (Barroso et al., 2000; Ferreira et al., 2007; Menaga et al., 2013; Jeena et al., 2014) and could bring diverse physiological benefits to the consumer, such as protection against human diseases associated with oxidative stress, like coronary heart disease and cancer (Halliwell and Gutteridge, 1999; Lindequist et al., 2005). Amount of protein, fat, carbohydrates as well as antioxidants like vitamin $\mathrm{A}, \mathrm{C}$ and $\mathrm{E}$ vary with genus as well as species of mushroom. Enormous reports are available related to nutritional value of mushrooms but knowledge gap exists when we examine enhancement of nutritional content using genetic manipulation. Increase in yield, production of sporeless strains, and resistance to pathogen are regularly reported but effect of mutation on nutritional composition is less studied. Hence, in our present study, effect of different mutagens on various nutritional parameters of C.calocybe indica, a specialty mushroom, was determined. Nutritive value of $C$. indica is comparable with other edible mushrooms (Zahid et al., 2010). Due to alkaline ash, high fiber content, low concentration of fats and carbohydrates; nutritionist recommend this mushroom as a diet good for people with hyperacidity, constipation, cardiac and diabetes problem (Kumar et al., 2012). It has excellent rehydration qualities; the dried produce attains $80-90$ per cent original weight in 10-15 minutes of soaking and hence has a high prospect in processing industries (Doshi et al., 1988). C. indica, was recommended for cultivation in 2004 in the state of Punjab. Since then studies have been conducted on its cultivation methodologies and 
nutritional qualities but its genetic improvement has not been undertaken. Therefore, the present investigation was conducted to assess the nutritional composition of mutants of $C$. indica produced by protoplast mutagenesis which could prove beneficial for obtaining mutant strain with high nutritional value.

\section{MATERIALS AND METHODS}

Calocybe indica, $\mathrm{Ci}-3$ protoplasts were isolated by the method employed by Mukherjee and Sengupta (1986) and were subjected to physical (UV rays) and chemical (alkylating-NTG, base analog-5, bromouracil and intercalating-ethidium bromide) mutagenic treatments. Four mutagenic treatments yielded 30 protoplast regenerants which were treated as putative mutants. On the basis of growth and enzyme studies seven mutants were selected, namely CMN-3, CMN-9, CMN-11, CMB-4, CME-2, CMU-2 and CMU-5 (Kaur et al., 2011). These mutants were then compared with the parent strain, Ci-3 for their nutritional content (protein, soluble sugars, starch, fat, vitamins and ash content). The materials and methods employed for their analysis are described below:

Analysis of crude protein: Crude protein was estimated by Macro-Kjeldhal method. Ten grams of sample was digested in $800 \mathrm{ml}$ long neck macro -Kjeldhal flask using digestion mixture and the volume made to $100 \mathrm{ml}$ with distilled water. Distilled ammonia was absorbed in excess of $0.1 \mathrm{~N} \mathrm{HCl}$ and unneutralised $\mathrm{HCl}$ was back titrated against standardized $0.1 \mathrm{~N} \mathrm{NaOH}$ using methyl red as an indicator. Nitrogen was converted to per cent protein by multiplying with the factor 6.25 (BIS, 1981).

( $\mathrm{HCl}$ used by sample- $\mathrm{HCl}$ used by control $\times$ Normality of $\mathrm{HCl} \times 14 \times 100$

Nitrogen $\%=$

$$
\text { Wt. of sample } \times 100
$$

Analysis of total soluble sugars: Half gram of stored dried material was used for estimation of sugars. Free sugars were quantitatively extracted first with 80 per cent ethanol (two times) and then with 70 per cent ethanol (four times) using boiling water bath. From the pooled test extract containing free sugars, ethanol was removed at $40^{\circ} \mathrm{C}$ under diminished pressure to get aqueous syrup. The concentrated sugar syrup was quantitatively transferred to $100 \mathrm{ml}$ volumetric flask and volume was made to $98 \mathrm{ml}$ with distilled water. One $\mathrm{ml}$ of saturated solution of basic lead acetate was added to precipitate the proteins and final volume was made to about $100 \mathrm{ml}$. The contents were filtered through Whatman filter paper no.1. The excess lead ions in the filtrate were removed through precipitation with sodium oxalate crystals and filtered off. The clear protein free extract, so obtained, was then used for the determination of free sugars. Total reducing sugar was estimated using Dubois method (1956).

Analysis of starch: Extraction of starch was done from the sugar free residue. Starch was analysed using method of Clegg (1956). To 200mg dried sugar free residue, $5 \mathrm{ml}$ of water was added followed by addition of $6.5 \mathrm{ml}$ perchloric acid $(52 \%)$ in a $30 \mathrm{ml}$ centrifuge tube. All extraction steps were carried out at $2-5^{\circ} \mathrm{C}$ to avoid acid hydrolysis of starch. The centrifuge tubes were stirred continuously for 10 minutes and then intermittently for next 10 minutes. To this, $10 \mathrm{ml}$ distilled water were added and contents were centrifuged at $1500 \mathrm{~g}$ for 20 minutes. The supernatant, so obtained, was poured in a $50 \mathrm{ml}$ volumetric flask. The extraction procedure was repeated with the pellet but here the time of stirring was extended to 30 minutes. The supernatants were pooled, raised to $50 \mathrm{ml}$ with water and filtered through Whatman no. 1 filter paper, discarding first $5 \mathrm{ml}$ of filtrate. Estimation was done in similar manner for total sugars. The estimated value was multiplied with a factor of 0.9 to convert the sugars into starch.

Analysis of crude fat: Pet ether $\left(60-80^{\circ} \mathrm{C} \mathrm{BP}\right)$ soluble fat was extracted in a soxhlet apparatus for about 16 hours. After extraction, the solvent was evaporated over the steam bath and the residue was oven dried at $70^{\circ} \mathrm{C}$ to a constant weight (AOAC, 1990).

\section{Analysis of vitamins}

Ascorbic acid: The titrametric method using 2,6dichlorophenol indophenol dye was used to estimate ascorbic acid. Ten grams of crushed sample was taken and $100 \mathrm{ml}$ of volume was made up with $0.4 \%$ oxalic acid solution. The mixture was filtered through Whatman filter paper no. 1. To a measured volume of aliquot $(10 \mathrm{ml}), 15 \mathrm{ml}$ of oxalic acid $(0.4 \%)$ was added followed by titration against standardized dye (0.04\%) to a pink end product which persisted for at least 15 second. Fresh dye solution and standardized ascorbic acid was prepared before each analysis (AOVC, 1996).

Dye used by sample $\times$ Dye factor $\times$ Volume made $\times 100$

$\mathrm{mg}$ of ascorbic acid/100g =

Aliquot taken $\times$ Wt. of sample

Tocopherol: Total lipid was extracted by the cold extraction method of Folch et al. (1957). $500 \mathrm{mg}$ of dried sample was homogenized using pestle mortar in chloroform: methanol $(2: 1 \mathrm{v} / \mathrm{v})$, isopropanol $(10 \%$ in methanol) was added to stop the activity of phospholipases. The mixture was transferred to conical flasks and shaken well for an hour. After filteration through sintered funnel, the residue was again homogenized with chloroform: methanol solvent and filtered. Two extracts were pooled to get the crude lipid fraction. The extracts were transferred to separating funnels and $0.9 \mathrm{~N} \mathrm{NaCl}\left(1 / 5^{\text {th }}\right.$ of the total volume $)$ was added to make the extract free of impurities. The contents were shaken well and allowed to separate overnight. The lower layer containing chloroform and lipid was collected while the upper layer of impurities dissolved with $\mathrm{NaCl}$ was given three washings each with $10 \mathrm{ml}$ 
Table 1. Nutritional composition of mutant strains.

\begin{tabular}{|c|c|c|c|c|c|c|c|c|c|c|}
\hline $\begin{array}{l}\text { S. } \\
\text { N. }\end{array}$ & Mutants & $\begin{array}{l}\text { \% } \\
\text { Crude } \\
\text { protein }\end{array}$ & $\begin{array}{l}\text { Sugar } \\
\text { (g/100g } \\
\text { ) }\end{array}$ & $\begin{array}{l}\text { Starch } \\
(\mathrm{g} / \mathbf{1 0 0 g})\end{array}$ & $\begin{array}{l}\% \\
\text { Ash }\end{array}$ & $\begin{array}{l}\text { Toco- } \\
\text { pherol } \\
(\mathrm{mg} / 100 \mathrm{~g})\end{array}$ & $\begin{array}{l}\beta \text { - } \\
\text { carotene } \\
(\mu \mathrm{g} / \mathrm{g})\end{array}$ & $\begin{array}{l}\text { Lyco- } \\
\text { pene } \\
(\mu \mathrm{g} / \mathrm{g})\end{array}$ & $\begin{array}{l}\text { Fat } \\
\text { (g/100g) }\end{array}$ & $\begin{array}{l}\text { Ascorbic } \\
\text { acid } \\
(\mathrm{mg} / 100 \\
\mathrm{g})\end{array}$ \\
\hline 1 & CMU-2 & 11.23 & 2.91 & 3.07 & 18 & 15.29 & 9.3 & 7.60 & 2.43 & 15.94 \\
\hline 2 & CMU-5 & 15.60 & 3.31 & 3.18 & 17 & 17.36 & 2.8 & 1.67 & 1.30 & 10.94 \\
\hline 3 & CME-2 & 14.04 & 3.12 & 2.98 & 18 & 21.06 & 4.9 & 5.04 & 2.46 & 14.58 \\
\hline 4 & CMN-3 & 9.28 & 3.39 & 3.12 & 24 & 13.77 & 2.9 & 1.90 & 1.34 & 21.88 \\
\hline 5 & CMN-9 & 15.16 & 3.43 & 3.15 & 11 & 18.48 & 11.7 & 7.40 & 1.24 & 8.85 \\
\hline 6 & CMN-11 & 13.50 & 3.29 & 3.08 & 34 & 17.04 & 4.4 & 2.27 & 1.77 & 9.38 \\
\hline 7 & CMB-4 & 15.57 & 3.41 & 3.13 & 30 & 16.20 & 4.9 & 3.70 & 2.04 & 11.98 \\
\hline 8 & $\mathrm{Ci}-3$ & 11.47 & 2.75 & 3.00 & 10 & 13.98 & 5.1 & 3.41 & 1.44 & 14.06 \\
\hline \multicolumn{2}{|c|}{$(\mathrm{CD} \mathrm{p}=0.05)$} & 0.887 & 0.42 & 0.11 & 3.67 & 0.545 & 0.51 & 0.08 & 0.127 & 0.657 \\
\hline
\end{tabular}

Results show mean of 3 trials and critical difference has been determined using IRRISTAT version $4.02 \mathrm{~b}$

chloroform to remove any residual lipids. Chloroform washings were pooled with earlier lipid extract and final volume made to $50 \mathrm{ml}$. This extract was used to determine tocopherol (Jayaraman, 1981).

$\boldsymbol{\beta}$-carotene and lycopene: The dried methanolic extract $(100 \mathrm{mg})$ was vigorously shaken with $10 \mathrm{ml}$ of acetone-hexane mixture (4:6) for 1 minute and filtered through Whatman No. 1 filter paper. The absorbance of the filtrate was measured at 453, 505, 645 and $663 \mathrm{~nm}$. The contents of $\beta$-carotene and lycopene were calculated according to equations as deduced by Nagata and Yamashita, 1992:

Lycopene $(\mathrm{mg} / 100 \mathrm{ml})=-0.0458 \mathrm{~A}_{663}+0.372 \mathrm{~A}_{505}-$ $0.0806 \mathrm{~A}_{453}$

$\beta$-carotene $(\mathrm{mg} / 100 \mathrm{ml})=0.216 \mathrm{~A}_{663}-0.304 \mathrm{~A}_{505}+$ $0.452 \mathrm{~A}_{453}$

The results were expressed as $\mathrm{mg}$ of carotenoid/g of extract.

Analysis of ash content: Two grams of dried sample was accurately weighed in a crucible. The sample was ignited on flame and finally ashed in furnace at $500 \pm 10^{\circ} \mathrm{C}$ to a constant weight till white ash was obtained using method of AOAC, 2000. The ash content was calculated as:

$$
\% \text { ash }=\frac{\text { Weight of residue }}{------\times 100}
$$

Statistical analysis.

Analysis of variance (ANOVA) was carried out using IRRISTAT version 4.02b (IRRI, 2000). Critical difference (CD) at a 0.05 level of probability was used to test the significance of differences among treatment means.

\section{RESULTS AND DISCUSSION}

C. indica mutants were evaluated for their protein, sugar, vitamins, ash and fat content. Protein tends to be present in an easily digested form in mushrooms (Chang and Buswell, 1996; Chang and Mshigeni, 2001). Mushroom protein contains all the essential amino acids needed in the human diet and are especially rich in lysine and leucine which are lacking in most staple cereal foods (Chang and Buswell, 1996; Sadler, 2003). Evaluation of crude protein in case of $C$. indica mutants indicated a range of 9.28-15.60\% protein. Five mutants (CMU-5, CMN-9, CMN-11, $\mathrm{CMN}-2$ and CMB-4) indicated higher protein content in comparison to that of $\mathrm{Ci}-3$ while $\mathrm{CMN}-3$ showed low protein content (Table 1). Saranya et al. (2011) reported protein content of $7.3-7.6 \mathrm{mg} / \mathrm{g}$ in $C$. indica grown on different substrate.

Total sugar content was estimated more for five mutants (CMU-5, CMN-3, CMN-9. CMN-11 and CMB-4) whereas sugar content of CMU-2 and CME-2 was at par with parent, Ci-3. Four mutants indicated more starch content (CMU-5, CMN-3, CMN-9 and CMB-4). Forty nine percent of carbohydrate has been reported in $C$. indica (Pushpa and Purushothama, 2010). Mushrooms are low in total fat content and have a high proportion of polyunsaturated fatty acids. Sumathy et al., (2015a) determined fat content in $C$. indica and determined it to be $3.13 \%$. Fat content in our samples was found to be significantly low only in mutant CMN-9 (1.24g/100g) which makes it preferable diet source for diabetic patients while all other mutants showed fat content at par or higher than the parent strain $(1.44 \mathrm{~g} / 100 \mathrm{~g})$.

Vitamin $\mathrm{C}$ is regarded as the first line natural antioxidant defense in plasma and a powerful inhibitor of LPO (Maxwell, 1995). Vitamin C is a water soluble antioxidant. It acts as a free radical scavenger. It scavenges peroxy radicals (Sies, 1993). Vitamin C protects non-smokers against the harmful effects of ROS from passive smoking (Jacob, 2000). The levels of vitamin $\mathrm{C}$ in mutants ranged from $8.85 \mathrm{mg} / 100 \mathrm{~g}$ for CMN-9 to $21.88 \mathrm{mg} / 100 \mathrm{~g}$ for CMN-3. Suganya and Suriyavathana (2012) reported $84 \mu \mathrm{g} / \mathrm{g}$ of vitamic C in C. indica. Tocopherols (or TCP) are a class of chemical compounds of which many have vitamin E activity. It is a series of organic compounds consisting of various methylated phenols. Tocopherol content was also higher for all the mutants except $\mathrm{CMN}-3$ which was at par with parent $\mathrm{Ci}-3$. CME-2 showed maximum 
tocopherol content of $21.06 \mathrm{mg} / 100 \mathrm{~g}$ of dry weight. Vitamin $\mathrm{E}$ of amount $42.2 \mu \mathrm{g} / \mathrm{g}$ has been determined by Suganya and Suriyavathana (2012) in C. indica. Djajanegara and Harsoyo (2008) reported increase in antioxidant property of Pleurotus florida mutant developed through irradiation. An increase of 2.5 fold has been recorded in one of the mutant PO-4 as compared to parent strain.

$\beta$-Carotene, an organic compound, classified as a terpenoid is an antiaging micronutrient of the highest order. In present study, $\beta$-carotene was more from 2 mutants CMU-2 and CMN-9 whereas CMN-11, CME -2 and CMB-4 showed $\beta$-carotene level at par with that of parent while that of CMU-5 and CMN-3 was less than that of the parent. Lycopene (carotenoid) content was better in CMU-2, CMN-9, CME-2 and CMB-4 while others showed less lycopene content than that of parent Ci-3. Sumathy et al., (2015b) analyzed non-enzymatic antioxidants of Calocybe indica var. APK2 and reported $112.73 \mu \mathrm{g} / 100 \mathrm{~g}$ of $\beta$-carotene and $22.42 \mu \mathrm{g} / 100 \mathrm{~g}$ of lycopene in their fruit bodies. Ash is the inorganic residue remaining after the water and organic matter have been removed by heating in the presence of oxidizing agents, which provides a measure of the total amount of minerals within a food. Krishnakumari et al., 2013 analyzed ash content of Calocybe indica and found out it to be around 14.14 $\%$. In our study ash content of parent strain was $10 \%$ while mutants showed ash content ranging from 11- 34 $\%$ with maximum being in $\mathrm{CMN}-11$.

To sum up, $C$. indica mutants were evaluated for their nutritional profile. Five mutants (CMU-5, CMN-9, CMN-11, CMN-2 and CMB-4) indicated higher protein content in comparison to that of $\mathrm{Ci}-3$. Total sugar content was also estimated more for five mutants (CMU-5, CMN-3, CMN-9, CMN-11 and CMB-4). Four mutants indicated more starch content (CMU-5, CMN-3, CMN-9 and CMB-4). Ash content was also found more for all the mutants except CMN-9. Tocopherol content was also higher for all the mutants except CMN-3. $\beta$-carotene was more from 2 mutants, CMU-2 and CMN-9. Lycopene content was better in CMU-2, CMN-9, CME-2 and CMB-4 while ascorbic acid content for CMU-2 and CMN-3 was better than that of the parent. Fat content was found to be significantly low only in mutant CMN-9 (1.24g/100g) as compared to $\mathrm{Ci}-3(1.44 \mathrm{~g} / 100 \mathrm{~g})$ while all other mutants gave fat content at par or higher than the parent strain.

\section{Conclusion}

This is the first report related to study of nutritional variation among mutants in Calocybe indica produced by mutation of protoplats. CMN-9 has been found to have high protein, carbohydrate, tocopherol, lycopene and least fat content. It is found to be more superior in terms of nutrition in comparison to the parent strain. Hence, strains need to be genetically exploited in order to enhance their nutritional properties which will lead to fulfillment of food needs in terms of both quantity as well as quality.

\section{REFERENCES}

AOAC. (1990). Official Methods of Analysis. Association of Official Analytical Chemists. $13^{\text {th }}$ edition, Washington, D.C.

AOAC. (2000). Official Methods of Analysis, $7^{\text {th }}$ ed. Association of Official Analytical Chemists. Gaithersburg, MD, USA

AOVC. (1996). Methods of vitamin assay. Association of Vitamin Chemists inc. (ed.) Interscience publishers, pp 306-12.

Barroso, G., Sonnenberg, A.S., Van Griensven, L.J. and Labarere, J. (2000). Molecular cloning of widely distributed microsatellite core sequence from the cultivated mushroom Agaricus bisporus. Fungal Genetics and Biology, 31: 115-23.

BIS. (1981). Handbook of Food Analysis. Part XI, Dairy Products. Bureau of Indian Standards, New Delhi.

Chang, S.T. and Buswell, J.A. (1996). Mushroom nutriceuticals. World Journal of Microbiology and Biotechnology, 12: 473-476.

Chang, S.T. and Mshigeni, K.E. (2001). Mushroom and their human health: their growing significance as potent dietary supplements. The University of Namibia, Windhoek, 1-79, pp1188-1194.

Chittaragi, A. and Naika, R. (2014). Determination of trace elements on some wild mushroom samples encountered from Western ghats of Karnataka. Journal of Chemical and Pharmaceutical Research, 6: 2124-2135

Clegg, K.M. (1956). The application of the anthrone reagent to the estimation of starch in cereals. Journal of the Science of Food and Agriculture 7: 40-44.

Cooper, E.L. (2008). Ayurveda and eCAM: a closer connection. Evid Based Complement Alternat Med., 5: $121-2$

Doshi, A., Munot, J.F. and Chakravarti, B.P. (1988). Nutritional status of an edible mushroom Calocybe indica (P\&C). Indian Journal of Mycology Plant Pathology, 18: 301-302.

Dubois, M., Gilles, K.A., Hanilton, J.K., Rebers, P.A. and Smith, F. (1956). Colorimetric method for the determination of sugars and related substances. Analytical Chemistry, 28: 350-356.

Durgo, K., Koncar, M., Komes, D., Belscak-Cvitanovic, A., Franekic, J., Jakopovich, I., Jakopovich, N. and Jakopovich, B. (2013). Cytotoxicity of Blended Versus Single Medicinal Mushroom Extracts on Human Cancer Cell Lines: Contribution of Polyphenol and Polysaccharide Content. International Journal of Medicinal Mushrooms, 15: $435-448$

Ferreira, I.C.F.R., Baptista, P., Vilas-Boas. and Barros, L. (2007). Free-radical scavenging capacity and reducing power of wild edible mushrooms from northeast Portugal: Individual cap and stipe activity. Food Chemistry, 100: 1511-1516.

Folch, J., Lees, M. and Sloane-Stanley, G.H. (1957). A simple method for isolation and fructification of total lipids from animal tissue. The Journal of Biological Chemistry, 226: 497-509

Gan, C.H., Nurul Amira, B. and Asmah, R. (2013). Antioxidant analysis of different types of edible mushrooms 
(Agaricus bisporous and Agaricus brasiliensis). International Food Research Journal, 20 : 1095-1102

Guo, J.Y., Han, C.C. and Liu, Y.M. (2010). A Contemporary Treatment Approach to Both Diabetes and Depression byCordyceps sinensis, Rich in Vanadium. Evid Based Complement Alternat Med., 7: 387-389.

Halliwell, B. and Gutteridge, J.M.C. (1999). Free Radicals in Biology and Medicine”, 3rd Edn., Oxford University Press, New York, USA., ISBN-13: 9780198500452 , Pages:pp 936.

Jacob, R.A. (2000). Passive smoking induces oxidant damage preventable by vitamin C. Nutr. Rev., 58: 239- 241

IRRI (International Rice Research Institute). (2000). IRRISTAT for window (CD-ROM) version 4.02b. Los Banus. Phillipines

Jayaraman, J. (1981). Estimation of vitamin E. In : Laboratory Manual in Biochemistry. MS Sejwal, New Delhi pp 111.

Jeena, G.S., Punetha, H., Prakash, O., Chandra, M. and Kushwala, K.P.S. (2014). Study on in vitro antioxidant potential of some cultivated Pleurotus species (Oyster mushroom). Indian Journal of Natural Products and Resources, 5: 56-61

Kaur, J., Sodhi, H.S., Kapoor, S., Khanna, P.K. and Jaswal, R.K. (2011). Strain improvement of specialty mushroom , Calocybe indica, though mutagenesis. Applied Biological Research, 13: 62-69

Krishnakumari, S., Rajeswari, P. and Kathiravan, S. (2013) Ameliorative effect of Calocybe indica, a tropical Indian edible mushroom on hyperglycemia induced oxidative stress. International Journal of Biological, Food, Veterinary and Agricultural Engineering, 7: 279-282

Kumar, R., Singh, G., Mishra, P. and Singh, R. (2012). Effect of different organic supplements and casing mixtures on yield of two strains of milky mushroom (Calocybe indica). Indian Phytopath., 65: 399-403

Lindequist, U., Niedermeyer, T.H.J. and Julich, W. (2005). Pharmacological potential of mushrooms. eCAM, 2: 285-299.

Maxwell, S.R.J., (1995)., " Prospects for use of antioxidant therapies.", Drugs., 49, pp: 345-361.

Menaga, D., Rajakumar, S. and Ayyasamy, P.M. (2013). Free radical scavenging activity of methanolic extract of Pleurotus florida mushroom. International Journal of Pharmacy and Pharmaceutical Sciences, 5: 601-606
Mukherjee, M. and Sengupta, S. (1986). Mutagenesis of protoplasts and regeneration of mycelium in the mushroom Volvariella volvacea. Applied and Environmental Microbiology, 52: 1412-14.

Nagata, M. and Yamashita, I. (1992). Simple method for simultaneous determination of chlorophyll and carotenoids in tomato fruit", Nippon Shokuhin Kogyo Gakkaish, 39: 925-928.

Sadler, M., (2003)., " Nutritional properties of edible fungi",. British Nutrition Foundation Nutritional Bulletin, 28, 305-308.

Pushpa, H. and Purushothama, K.B. (2010) Nutritional analysis of wild and cultivated edible medicinal mushrooms. World Journal of Diary and Food Sciences, 5: 140-144

Saranya, V., Madhanraj, P. and Panneerselvam, A. (2011). Cultivation, composting, biochemical and molecular characterization of Calocybe indica (C and A). Asian Journal of Pharmaceutical Research, 1: 55-57

Sies, H. (1993). Strategies of antioxidant defence. European Journal of Biochemistry, 215: 213-219.

Suganya, M. and Suriyavathana, M. (2012). Antioxidant profile of Agaricus bisporus and Calocybe indica. International Journal of Pharmacy and Life Sciences, 3: 1780-1783

Sumathy, R., Kumuthakalavalli, R. and Krishnamoorthy, A. S. (2015a) Proximate vitamin, aminoacid and mineral composition of milky mushroom, Calocybe indica (P\&C). Var. Apk2 commonly cultivated in Tamil Nadu, Journal of Natural Product and Plant Resources, 5: 38-43

Sumathy, R., Kumuthakalavalli, R., Krishnamoorthy, A.S. and Balan V. (2015b). Effect of phytochemicals and antioxidant compounds enriched extract from Calocybe Indica var. APK2 on proliferation of human MCF-7 breast carcinoma cells. Der Pharmacia Sinica, 6:6-11

Wang, X.M., Zhang, J., Wu, L.H., Zhao, Y.L., Li, T., Li, J.Q., Wang, Y.Z. and Liu, H.G. (2014). A mini-review of chemical composition and nutritional value of edible wild-grown mushroom from China. Food Chemistry, 151: 279-295

Zahid, K., Barua, S. and Haque, S.M.I. (2010). Proximate Composition and Mineral Content of Selected Edible Mushroom Varieties of Bangladesh. Bangladesh Journal of Nutrition. , Vol. 22-23 